\title{
A Study Regarding the Relationship between the Consumer Expectations Regarding Packaging and Brand Awareness*
}

\author{
Selda Ene ${ }^{1}$, Betül Özkaya ${ }^{2}$ \\ ${ }^{1}$ Vocational High School of Social Sciences, Marmara University, İstanbul, Turkey \\ ${ }^{2}$ Faculty of Communication, Marmara University, İstanbul, Turkey \\ Correspondence: Selda Ene, Vocational High School of Social Sciences, Marmara University İstanbul, Turkey. Tel: +90 \\ 53237496 86. E-mail: seldaene@marmara.edu.tr
}

Received: March 2, 2016

doi:10.5539/ibr.v9n6p102

\author{
Accepted: March 14, 2016 \\ Online Published: April 11, 2016 \\ URL: http://dx.doi.org/10.5539/ibr.v9n6p102
}

\begin{abstract}
Factors such as changing life styles, consumers being more conscious and competition increasing in both global and national domain require brands to seek success in the market by adding new and diversified characteristics to their products. In this context, packaging, which adds value to the product and moreover, presents the product on the shelves and is a part of the product and the brand, is a subject that the brands and the consumers increasingly focus on. Packaging is crucial in the marketing of similar products. Thus, it bears a lot of responsibility.

Packaging reaches both available and potential consumers at the most essential stage like decision-making and satisfies the expectations of the consumers, such as "information seeking, ease of handling and usage, brand comparison, brand image and awareness, environment protection, health insurance, innovation opportunity, promotion, etc." Packaging is situated in an important position in reaching the consumer, being imprinted on people's mind and creating brand awareness. Due to the fact that packaging is the initial attraction factor in points of purchase, it is one of the most important aspects of the brand and it helps to increase the brand value by creating brand awareness. Deriving from this notion, this study analyzes the relationship between the consumer expectations regarding packaging and brand awareness with the help of a survey. For the survey, consumers who are over 18 years old and shop from the food retail stores are interviewed face to face in İstanbul, Turkey on August 2015 and convenience sampling method has been used. Factor analysis was applied to the data which were obtained from the survey. In this study, the relationship between the consumer expectations regarding packaging and brand awareness is examined by performing a regression analysis. It is hoped that the study results will be a guideway for the corporations that seek to increase brand awareness and it is believed that this will increase the awareness level, emphasizing the importance of packaging.
\end{abstract}

Keywords: packaging, consumer expectations, brand awareness

\section{Introduction}

Factors such as changing life styles, consumers getting more conscious and competition in both global and national domain require brands to seek success in the market by adding new and diversified characteristics to their products. In this context, packaging which adds value to the product and moreover, presents the product on the shelves and is a part of the product and the brand, is a subject that the brands and the consumers increasingly focus on (Sütütemiz, Çiftylldız \& Konuk, 2009). When today's consumers are analyzed, it is viewed that they purchase the products not only for their functional features, but also for their symbolic meanings. For example, elegant and decorative packaging such as original perfume bottles, balm cases could be the reason for preference for the consumers. Therefore, correct positioning is essential in marketing similar products and thus, packaging bears a lot of responsibility. In this case, packaging assumes the role of a silent salesman and is one of the tools that communicates with the consumer and conveys the message that the manufacturer intended to convey (Alagöz \& Ekici, 2009). In other words, packaging is becoming one of the most integrated marketing communication tools. The reason is, packaging reaches the present and the potential customers at the most crucial decision-making moment, the consumers examine the packaging for the

\footnotetext{
* This paper has been presented at IX. European Conference on Social and Behavioral Science in Paris, France, February 3-6, 2016.
} 
correct information and they actively prepare themselves for the communication process. In this context, packaging is becoming one of the most crucial stimuli in creating brand identity. It conveys this to the consumers and contributes to empowering consumer-brand relationship (Sütütemiz et al., 2009).

Packaging is one of the most influential tools in reaching the consumer, being imprinted on people's mind and creating brand awareness. A consumer has to be aware of the brand, before purchasing that particular brand. Therefore, if the consumers are not aware of the brand, there will be no brand preference, nor purchase intent. In order to create awareness and to maintain this awareness, certain principles in the field of psychology and advertisement are employed. These principles involve various awareness-rising methods such as creating a bond with consumers through mottos and jingles, brand sticking into mind by transforming into a symbol and making consumer to be aware of the brand with the brand mark. However, the first impression of the product occurs when the consumer encounters the product for the first time at the point of purchase. Since the packaging excites attention in consumer from the start, packaging is one of the most important aspects of the brand (Aaker \& Keller, 1990) and helps to increase the brand value by creating brand awareness. Deriving from this notion, this study analyzes the relationship between the consumer expectations regarding packaging and brand awareness, with the help of a survey. For the survey, consumers who are over 18 years old and shop from the retail stores are interviewed face to face and convenience sampling method has been used. Factor analysis was applied to the data which were obtained from the survey. In this study, the relationship between the consumer expectations regarding packaging and brand awareness is examined by performing a regression analysis.

\section{Theoretical Framework}

It is becoming harder for the consumers who interact with countless messages every day, to enable their purchasing behavior. For this, packaging plays an important role to attract the consumer and to enable communication with the consumers (Yildiz, 2010).

Packaging is like the clothing of the product and the material that promotes and protects the product which it encloses, from the external factors while handling (Teke, 2014). More clearly, packaging is to enclose the product with a material that protects the content, enables its distribution, storage, sale and usage, which then can be covered, wrapped or assembled with a totally disposable or recycled material (Tek, 1999).

Packaging is the product feature which the consumer faces for the first time. For this reason, the corporations need to have a good grasp of the functions and the importance of packaging and they have to implement such packaging features to ideally satisfy the consumer expectations. In literature, packaging is generally known for the features of protection, storage and handling, ease of usage, providing amount and information, price regulation and promotion (Yükselen, 2003; Sezgin, Haşıloğlu \& Zerenler, 2008; Kocamanlar, 2009; Dilber, Dilber \& Karakaya, 2012).

When many benefits such as easy recognition of the product and ability to purchase in appropriate sizes are considered, it is apparent that the packaging features are now an expectation of consumers. Consumers now wish to be informed, convinced and surprised with intriguing, convincing packaging features and emotional impacts. Consumer expectations which comprise many aspects like quality, after-sales services, affordable prices, now appears in another format with appropriate packaging features. Since satisfying consumer expectations are essential in terms of consumer satisfaction, it is inevitable for the corporations to implement the packaging features that the consumers require (Sütütemiz et al., 2009). In this context, packaging increases its importance on consumers' lives day after day and it largely influences the consumers' purchase decisions by attracting consumers, protecting the product, presenting ease of usage and prolonging the product life. Packaging, at the same time, is the last point of persuasion before a consumer makes a purchase decision. For this reason, every feature that comprise the packaging such as color, design, shape, size, brand name, material, product information and suitability of consumption are essential to enable purchase behavior and to create brand awareness in consumer's mind (Kocabaş, Elden \& Çelebi, 1999; Yıldız, 2010).

A consumer has to be aware of the brand, before purchasing that particular brand. Awareness is the prerequisite for creating of perception and ideas for that particular brand (Uztuğ, 2008). Therefore, if the consumers are not aware of the brand, there will be no brand preference, nor purchase intent. Thus, brand awareness plays a crucial role in consumer purchase decision process. Brand awareness is the place in consumer's mind where the brand is compared with its competitors (Meral, 2011; Erciş, Yapraklı \& Can, 2009). In other words, figural and contextual features such as brand name, brand logo, packaging shape and brand benefits which enable brand positioning in consumers' minds are included in brand awareness topic (Tosun, 2014). Brand awareness levels which are used in awareness indication can be sorted as recognizability, recall, first brand in suggestion, brand dominance, brand information and brand opinion (Uztuğ, 2008).

Aaker (1991) defines the brand awareness as the potential consumer's ability to recognize and to remember that the brand belongs to a certain product category. Recognition is the consumer's ability to know the brand name and to distinguish the brand in accordance with his/her previous knowledge and experience when he/she is exposed to the 
visual characteristics of the brand or when hints regarding these visual features are given (Kirdar, 2003). Visual identification cues such as logos, mottos, names and emblems ease identification. These factors are important in fast moving consumer goods (Erdil \& Uzun, 2009). For example, when one sees a packaging containing a cow picture over a purple background, 'Milka' brand is recognized (Tosun, 2014). As such, recognition matters more in consumers' decision processes at points of purchase and the brands which could create awareness over other brands could become 'strong' brands (Yildı, 2010). Recall is the act of brand springing to mind when the consumer requires the function of a product. For example, when one needs a painkiller, the process of 'Minoset' springing to mind is recall (Tosun, 2014). So, recall can be associated with creating a strong market position by being positioned in consumers' minds (Yıldiz, 2010).

When the consumer makes a purchase decision, generally based on visual features at the point of purchase, this is recognition; and when he/she makes the purchase decision before entering the point of purchase, this is recall. Though, enabling brand recognition is easier compared to brand recall, the importance of recall is much higher (Tosun, 2014).

When relevant literature is reviewed, many researches regarding consumers' expected packaging features, the effect of packaging on the brand, consumer attitudes and behaviors towards packaging and the influence of packaging on consumer preferences become prominent. The findings of the studies conducted throughout the world and in Turkey can be summarized as follows;

In their study in which Carpenter, Cornforth \& Whittier (2001) have determined that in preference of packaged fresh meat products, they have deduced that the packaging plays an important role. In addition to this, they have also stated that the color of the meat and the packaging format also contribute to the purchase decision.

In their study, Rex, Wai \& Lobo (2004) have discussed potato chips packaging and they have determined that the packaging size, shape and the color is very influential in decision making process. Besides the packaging, they have also deduced that the price, brand, taste and the quality are also regarded product qualities.

In their study, Dantas, Minim, Deliza, \& Puschmann (2004) have discussed fresh and minimally processed green-leaved vegetables and they have determined that the color of the packaging, the visibility of the content and the information on the package stand out.

In the study, Whaling (2007) has analyzed the packaging of cherry juice and it was deduced that the consumers prefer the glass bottle which enable the visibility of content. Moreover, it was deduced that the features such as being natural, robust, recycled, easy-to-pour, capped, easy-to-handle and use are preferred by the consumers.

In their study, Brodersen \& Monolova (2008) have determined that the consumers who shop for fast moving products such as shampoos and toilet papers shop without researching and thinking intensively and stated that they are influenced by the visual stimuli and they make decisions at the spot.

In their study, Örücü \& Tavşancı (2001) have tried to determine if the product packaging have any effect on consumer behavior when choosing a food product. In the study, they have concluded that all functions that comprise the packaging such as package color and the label on it, ease of portability are all influential on consumer behavior.

In the study, Koyuncu (2007) has studied whether there is a difference between the importance level of the brand and the packaging and price perception levels. In the conclusion, it was stated that consumers' past experiences and product price are highly influential in preference of certain brand and packaging.

In the study, Gökalp (2007) has aimed to find out at which level the consumers are influenced by the packaging when they shop for food products in the city of İzmir. In the conclusion, it was determined that the consumers generally prefer packaged products, due to believing that it's healthier, but they also thought that the packaging increases the price of the product.

In their study, Sütütemiz et al. (2009) have stated that packaging features are the product characteristics that are taken into consideration and the visual characteristics of packaging have suggestive effects on unplanned purchase decisions and the informative notes on packaging have suggestive effects on re-purchase intent.

Alagöz \& Ekici (2009) have conducted a survey, consisting of 350 consumers in Karaman in their study. The study concluded that there are suggestive differences between the perspectives of women and men consumers regarding the necessity of capped products for re-usability, the content being proportional to the package size and the importance of recycle-loop characteristics.

In their study, Dilber et al. (2012) have tried to determine the importance of the packaging for the consumer with a survey. In the conclusion, it was determined that the consumers generally prefer packaged products, due to believing that it's healthier, but they also thought that the packaging increases the price of the product. 


\section{A Study of the Relationship between the Consumer Expectations Regarding Packaging and Brand Awareness}

\subsection{Purpose and Scope of the Research}

Packaging is one of the most influential tools in reaching the consumer, being imprinted on people's mind and creating brand awareness. A consumer has to be aware of the brand, before purchasing that particular brand. However, the first impression of the product occurs when the consumer encounters the product for the first time at the point of purchase. Since the packaging excites attention in consumer from the start, packaging is one of the most important aspects of the brand (Aaker \& Keller, 1990) and helps to increase the brand value by creating brand awareness. Deriving from this notion, this research analyzes the relationship between the consumer expectations regarding packaging and brand awareness, with the help of a survey.

The survey was based on the literature browsing and was subjected to a preliminary test. The results of the preliminary test enabled the correction of misconceptions in the survey and these were applied to the sample audience. The main mass variety which would represent Turkey was accessed via pollsters in the city of İstanbul.

For the research, consumers who are over 18 years old and shop from the food retailer stores were interviewed face to face and convenience sampling method has been used. In the survey, topics such as "Consumer Expectations Regarding Packaging and Brand Awareness" were examined with Likert. Likert Scale was used (1. Definitely Disagree, 2. Disagree, 3. Neutral, 4. Agree, 5. Definitely Agree). The topic of "The Consumer Expectations Regarding Packaging" was subjected to factor analysis and as a result of factor analysis, whether there is a relation between deduced variables and "Brand Awareness" in retail stores are analyzed with regression analysis.

\subsection{Research Methodology}

Limits of research, the research model and bulk sample selection of research are presented below.

\subsubsection{Limits of Research}

In this study, the "Consumer Expectations Regarding Packaging" and the "Brand Awareness" in the retail store are analyzed with a survey. The constraint for the main mass of the study is to be comprised of individuals that are over 18 years of age and are able to decide, by their own rights, to shop from food retail stores in İstanbul in Turkey on August 2015 and the application of survey study was conducted with the shoppers in the hours in which the shops were open. Survey study has been performed by interviewing face to face with 550 individuals by interviewers who conduct the survey. Convenience sampling method has been used.

\subsubsection{Research Model}

The study model, which is created in order to explain "Consumer Expectations Regarding Packaging" and the Brand Awareness" exhibited during shopping, is as follows (Figure 3.1).

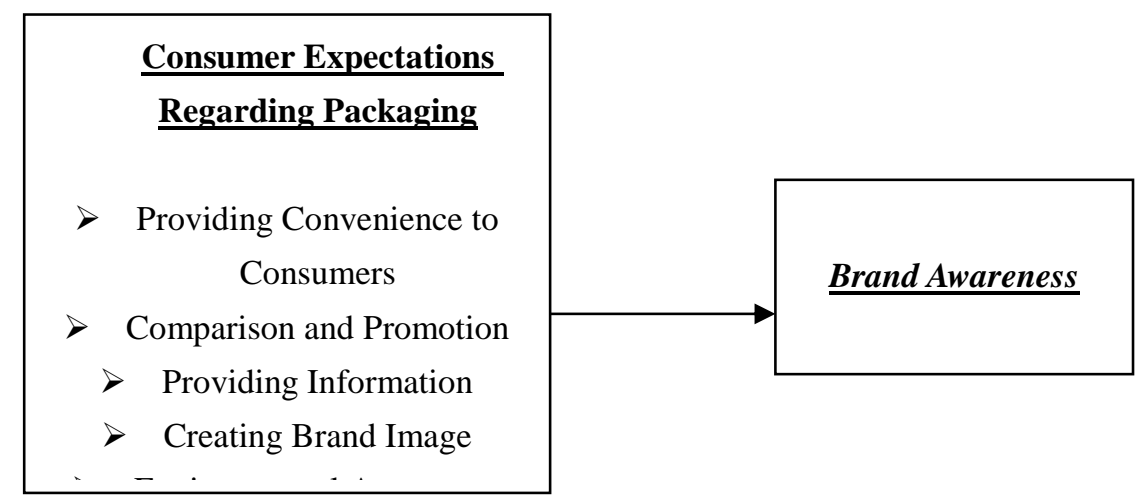

Figure 3.1. A Research Model on the Relationship Between "Consumer Expectations Regarding Packaging" and "Brand Awareness"

The hypothesis of the research is included below. By discussing this hypothesis, sub-hypothesis are created and analyses are made.

$\mathbf{H}_{\mathbf{1}}$ : There is a suggestive relation between "Consumer Expectations Regarding Packaging" and "Brand Awareness."

The scale for "Consumer Expectations Regarding Packaging" and "Brand Awareness" are created by referring to the sources included in the table below (Table 3.1). 
Table 3.1. "Consumer Expectations Regarding Packaging" and "Brand Awareness" Scale

\begin{tabular}{|c|c|}
\hline $\begin{array}{c}\text { VARIABLE } \\
\end{array}$ & SOURCE \\
\hline Consumer Expectations Regarding Packaging & Dilber, F., Dilber A. \& Karakaya, M. (2012) \\
\hline$>$ Providing Convenience to Consumers & Alagöz, S. B. \& Ekici, N. (2009, Aralık) \\
\hline$>$ Comparison and Promotion & Koyuncu, K. (2007) \\
\hline$>$ Providing Information & Teke, B. (2014) \\
\hline$>\quad$ Creating Brand Image & Whaling, A. M. (2007) \\
\hline Environmental Awareness & \\
\hline $\begin{array}{l}\text { Creating Diversity and Innovation } \\
\text { Opportunities }\end{array}$ & \\
\hline \multirow{3}{*}{ Brand Awareness } & Uztuğ, F. (2008) \\
\hline & Y1ldı, Ö. E. (2010) \\
\hline & Tosun, N. (2014) \\
\hline
\end{tabular}

\subsubsection{Determination of the Research Bulk Sample}

The survey work of the study has been conducted with face to face interviews with 550 individuals who were over 18 years of age that shop from retail stores in Turkey on August 2015 and convenience sampling method has been used.

\subsection{Findings of the Research}

The analysis of the study has been examined by separating into two sections: definitional and deductional.

\subsubsection{Definitional Analysis Findings}

The individuals who have participated in the survey are chosen from those who shop from retail stores, make their own minds in terms of shopping and are over 18 years old. The demographic features are presented by analyzing gender, education, income, age and marital status of 550 individuals. The consumers are comprised of 550 individuals, of which the $56.9 \%$ are women and $42.7 \%$ are men. The education status of these individuals is as follows: " $22 \%$ high school education, $50.9 \%$ associate degree, $24.2 \%$ undergraduate, $1.6 \%$ bachelor's degree and $1.3 \%$ post graduate and higher. The income distribution of consumers is as follows: $43.1 \%$ between $500-1,000 \mathrm{TL}, 33.8 \%$ between $1,001-2,000 ; 17.6 \%$ between 2,001 - 3,000 and 5.1\% between 3,001-4000. Age distributions are, 63.3\% between 18-25, 24\% between 26-35, $9.3 \%$ between $36-45,2.7 \%$ between $46-55$ and $1 \%$ over 56 . Consumers' marital statuses are $21.1 \%$ married, $65.5 \%$ single, $1.3 \%$ widower and $12.2 \%$ divorced.

The scale of "Consumer Expectations Regarding Packaging” consists of 26 questions. 26 questions are subjected to factor analysis and six factor groups are emerged; these are: These factor groups can be sorted as "Providing Convenience to Consumers, Comparison and Promotion, Providing Information, Creation of Brand Image, Environmental Awareness, Creating Diversity and Innovation Opportunities" (Table 3.2). With the factor results of the study, the consumer expectations regarding packaging are considered.

For "Consumer Expectations Regarding Packaging" variables comprised of 26 variables, at the end of performed credibility analysis, a significance level of 0.05 and Cronbach's Alfa Value of 0.937 have been determined. Alpha value carries values between 0 and 1 and it was desired for the admissible value to be at least 0.7 (Altunmış1k, Coşkun, Bayraktaroğlu \& Yıldırım, 2005). Therefore, it can be stated that the credibility of the scale is high.

In the factor analysis, which has been performed on the "Consumer Expectations Regarding Packaging" which consists of 26 questions; when Kaiser-Meyer-Olkin (KMO) sample efficiency test is applied; relevance value is found to be 0.000 and KMO value is found to be 0.904 . The test of factor analysis of practicability to any data set is measured with KMO sample efficiency test. The KMO values between 0.5-1.0 are deemed to be acceptable (Altunmışık et al., 2005). Therefore KMO value of 0.904 is believed to be sufficient enough for factor analysis.

Also, it has been examined that the six factors which have been obtained in the study have attested the $71.87 \%$ of total variance. The resulted factor groups and the factor loads are included in Table 3.2. 
Table 3.2. "Consumer Expectations Regarding Packaging” Factor Analysis Results

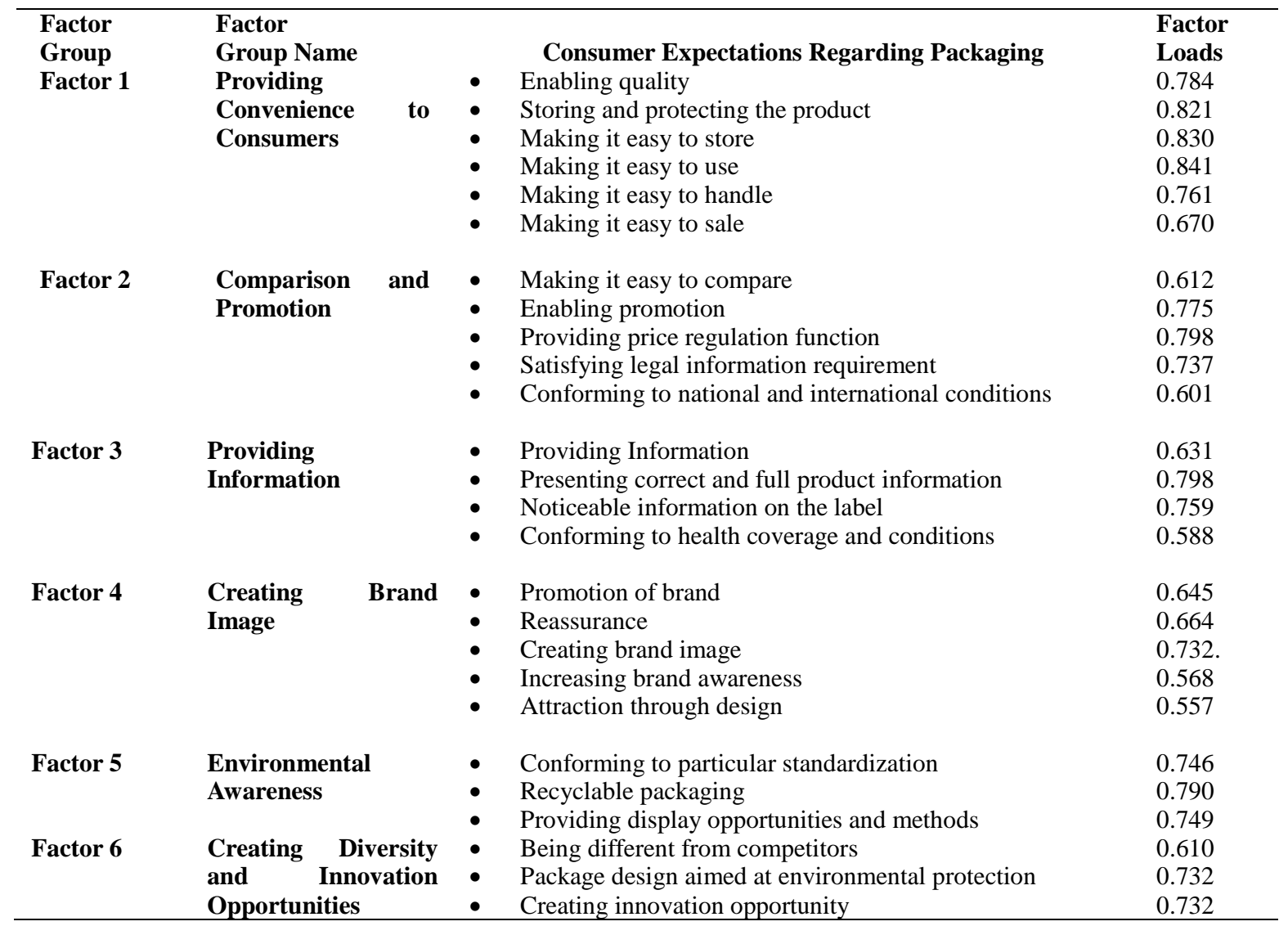

3.3.2 Deductional Analysis Findings

The deductional analysis of the study has been examined as follows:

The abbreviations for Dependent Variables "Brand Awareness" are included below.

- Brand Awareness: BA

The abbreviations for Independent Variables “Consumer Expectations Regarding Packaging” are included below.

- Providing Convenience to Consumers: PCC

- Comparison and Promotion: $\mathbf{C P}$

- Providing Information: PI

- Creation of Brand Image: CBI

- Environmental Awareness: EA

- Creating Diversity and Innovation Opportunities: CDIO

“Consumer Expectations Regarding Packaging” is made of 26 questions and six factor groups were emerged as a result of the factor analysis. Six factor groups form the independent variables of regression analysis.

Brand Awareness is thought to be a dependent variable and a hypothesis is created for independent variables, showed as an equation and its relationship with independent variables (Consumer Expectations Regarding Packaging) is analyzed with regression analysis.

In the regression analysis of the study; application has been made by integrating all variables with Stepwise Method for every hypothesis test. Due to various iterations, the model has emerged. In the testing of hypotheses in these studies, as a result of the iterations of the Stepwise Method, final model has been presented.

The main hypothesis of the study and regression analysis results regarding this hypothesis can be found below.

Hypothesis;

H1: There is a suggestive relation between Consumers" "Expectations Regarding Packaging" and "Brand Awareness." 
The regression formula explaining the relation in above hypothesis can be expressed with

$$
\mathrm{BA}=0.007+0.109 \mathrm{CP}+0.103 \mathrm{PCC}+0.087 \mathrm{PI}
$$

Table 3.3. The Regression Analysis Model Summary of the Relationship Between Consumers' "Expectations Regarding Packaging" and Brand Awareness

\begin{tabular}{lrccc}
\hline & & & & Standard Error of \\
Model & $\mathrm{R}$ & $\mathrm{R}^{2}$ & Adjusted $\mathrm{R}^{2}$ & Estimate \\
\hline 3 & 0.173 & 0.030 & 0.025 & 0.986 \\
\hline
\end{tabular}

Note. $\mathrm{R}=$ Regression, $\mathrm{R}^{2}=$ Regression Square

Table 3.4. Regression Analysis ANOVA Table of the Relationship Between Consumers' "Expectations Regarding Packaging" and "Brand Awareness"

\begin{tabular}{clccccc}
\hline Model & & $\begin{array}{c}\text { Sum of } \\
\text { Square }\end{array}$ & sd & $\begin{array}{c}\text { Average } \\
\text { Square }\end{array}$ & F & p - value \\
\hline 3 & Regression & 16,213 & 3 & 5,404 & 5,558 & 0,001 \\
& Residual & 526,072 & 547 & 0.972 & & \\
& & & & & & \\
& Total & 542,286 & 550 & & & \\
\hline
\end{tabular}

Note. $\mathrm{sd}=$ standard error of estimate $\mathrm{F}=\mathrm{F}$ change statistics, $\mathrm{p}$-value $=$ significant-value

The model which has been tested with regression analysis is statistically relevant $(\mathrm{F}=5.558$ and $\mathrm{p}=0.001)$. Because, relevance level of $\mathrm{F}$ value is smaller than $(\mathrm{p}<0.05), 0.05$.

Six factors, which have been obtained as a result of the factor analysis, constitute the independent variables of regression analysis. Our dependent variable is "Brand Awareness" (BA). As a result of regression analysis, it is seen that there are three factors which have a relevant effect on planned shopping and these independent variables that are: Comparison and Promotion (CP), Providing Convenience to Consumers (PCC), Providing Information (PT)." Independent variables explain the $0,030 \%$ ( $\mathrm{R}^{2}$ value) of the change in dependent variable.

Result of the regression analysis, "beta value (B) projection of the relation between Consumers' "Expectations Regarding Packaging" and "Brand Awareness", "standard error values, t values, p values and VIF values" are shown in Table 3.5.

Table 3.5. As a Result of the Regression Analysis of the Relationship Between Consumers' "Expectations Regarding Packaging" and "Brand Awareness" "Beta, Standard Error, t, p, VIF Value Results

\begin{tabular}{|c|c|c|c|c|}
\hline $\begin{array}{l}\text { Independent } \\
\text { Variables }\end{array}$ & & $\mathbf{C P}$ & PCC & PI \\
\hline $\begin{array}{ll}\text { Beta } & \text { Value } \\
\text { Values } & \end{array}$ & 0,007 & 0.109 & 0.103 & 0.087 \\
\hline Std. Error Value & 0,042 & 0.042 & 0.042 & 0.042 \\
\hline t Value & 0,170 & 2.566 & 2.429 & 2.047 \\
\hline p Value & 0,865 & 0.011 & 0.015 & 0.041 \\
\hline VIF value & & 1,000 & 1.000 & 1.000 \\
\hline
\end{tabular}

Note. $C P=$ Comparison and Promotion, $P C C=$ Providing Convenience to Consumers, $P I=$ Providing Information, $\mathrm{VIF}=$ Interaction between the variables.

" $\mathbf{H}_{\mathbf{1}}$ hypothesis has been tested with the regression analysis of there is a suggestive relation between consumers' "Expectations Regarding Packaging" and "Brand Awareness". As a result of the regression analysis, it has been examined that only three; "Comparison and Promotion (CP), Providing Convenience to Consumers (PCC), Providing Information (PI)" of the six factor groups, which constitute the independent variables, have suggestive, statistical effect on "Brand Awareness" and $\mathrm{H}_{1}$ hypothesis could not be validated. $\mathrm{H}_{1}$ hypothesis was partly validated for only three variables.

Deciding whether independent variables, which affect the "Consumer Expectations Regarding Packaging," possess multiple connections was accomplished by examining VIF values (ie. interaction between the variables) on the regression analysis table. In the statistical analyses, VIF values between 1-10 show that there is no correlation issue. In this study, VIF values of independent variables were examined, it was observed that all of them obtained values of 1.000 and therefore, due to the fact that they obtained values between 1 and 10 , it has been deduced that the variables did not affect each other. 


\section{As the result of conducted analysis;}

"H1 hypothesis has been tested with the regression analysis of there is a suggestive relation between Consumers' "Expectations Regarding Packaging" and "Brand Awareness". As a result of the regression analysis, only three variables out of the six factor groups comprising independent variables were found to be in a suggestive relation with "Brand Awareness." Comparison and Promotion (CP), Providing Convenience to Consumers (PCC), Providing Information (PI)" variables were found to have a statistical, suggestive effect on "Brand Awareness" and it is examined that none of the other independent variables are seen to have any other suggestive effect. $\mathrm{H}_{1}$ hypothesis could not be totally validated. H1 hypothesis was partly validated for only three variables.

"Comparison and Promotion (CP), is at 1st place with a 0.109 unit increase, Providing Convenience to Consumers (PCC), is at 2nd place with a 0.103 unit increase and Providing Information (PI)" is at third place with a 0.087 unit increase, prompting "Brand Awareness" in adjuvant direction.

\section{Conclusion and Assessment}

Brands need to become distinct by gravitating towards innovation in order to enable consumers focusing on their product and to be imprinted on their minds. Attaining a place in the market through differentiation is inevitable for the brands to create sustainable competitive advantage. Packaging plays an important in these brand differentiation efforts.

By enabling communication between the manufacturer and the consumer (Yükselen, 2003), packaging helps the corporation or the brand to be recognized by the consumers. Packaging should also satisfy the consumer in terms of aesthetics and should contain attractive aspects. The ability for a product to hold onto a place in the market depends not only on the correct and effective choice of packaging material, but also on the packaging design. An attractive, pleasant packaging with product-matching colors, fonts and layouts would influence the consumer positively. Other than these features, packaging is an effective tool in brand being imprinted on people's minds and creating brand awareness. Therefore, the corporations realize this importance and strive to create a differentiation in product packaging and a particular identity (Underwood, 2003).

For this purpose, this study has analyzed the "Consumer Expectations Regarding Packaging" and "Brand Awareness" in Turkey, with a survey. For the survey study, 550 consumers who are over 18 years of age and shop from the retail stores on August 2015 in Turkey, were interviewed face to face. Factor analysis and regression analysis were applied to the data that were obtained from the survey.

In this study, where the goal is to identify the consumers who shop from the retail stores in Turkey, the scale of Consumers' "Expectations Regarding Packaging"was subjected to factor analysis and six factor groups have emerged. These six factor groups are presented as "Providing Convenience to Consumers, Comparison and Promotion, Providing Information, Creation of Brand Image, Environmental Awareness, Creating Diversity and Innovation Opportunities."

As the result of the factor analysis of the study, the CDIO factor group of "Creating Diversity and Innovation Opportunities" has emerged in this study, with contrast to previous studies. The factor groups of the study were specified as the independent variable and its effect on "Brand Awareness" which is the dependent variable, was analyzed.

As a result of the regression analysis, only three variables out of the six factor groups comprising independent variables were found to be in a suggestive relation with "Brand Awareness." Comparison and Promotion, Providing Convenience to Consumers, Providing Information" variables were found to have a statistical, suggestive effect on "Brand Awareness" and it is examined that none of the other independent variables are seen to have any other suggestive effect.

Brand awareness is defines as the potential consumer's ability to recognize and to remember that the brand belongs to a certain product category (Aaker, 1991). The consumers make their purchase decisions for the fast moving consumer goods by distinguishing them when they are at the point of purchase or by remembering them. At this point, the ones which will become prominent and be successful will be the ones that could create brand awareness with factors such as packaging, etc. The corporations that evaluate consumer expectations regarding packaging will be able to create brand dependency and maintain customer loyalty. Factors such as "Comparison and Promotion, Providing Convenience to Consumers, Providing Information" will be the reason for satisfaction of consumer expectations regarding packaging and the customers will remember this. Therefore, their brand awareness towards the product and the services will increase. Retail corporations could get the edge on competitive environment and increase their successes.

The corporation managers should take packaging into account as an essential promotion factor in their efforts to increase brand awareness. They should track the expectations of the consumers towards packaging and should rapidly adapt to the novelties and innovations in packaging. Therefore, they will be able to come forward in consumers' minds as a brand that presents ease of use, information and comparison with their packaging both in commercials and in food retail stores. This will have a positive and success-adjuvant impact on corporations' brand positioning. 
This study contains information that can be considered beneficial for the corporations that seek to emphasize customer expectations and see packaging as an important factor in creating brand awareness. It is thought that the deduced findings will be beneficial for the national or international corporations. In addition to this, the findings of this study are limited to the sample of the study. However, it is believed to contain important results with regards to paving way for future studies.

In similar future studies, including customer expectations regarding packaging that varies from culture to culture and comparison at international levels would be highly beneficial in order to apprehend and clarify the subject in a better way.

\section{References}

Aaker, D. A. (1991). Managing brand equity: Capitalizing on the value of brand name, New York: The Tree Press.

Aaker, D. A., \& Keller, K. L. (1990). Consumer evaluations of brand extensions, Journal of Marketing, 54(1), 27-41. http://dx.doi.org/10.2307/1252171.

Alagöz, S. B., \& Ekici, N. (2009). Ambalaja ilişkin tutum ve davranışlar: Karaman ili araştırması, Karamanoğlu Mehmetbey Üniversitesi İktisadi ve İdari Bilimler Fakültesi Dergisi, 11(17), 84-94.

Altunışık, R., Coşkun, R., Bayraktaroğlu, S., \& Yıldırım, E. (2005). Sosyal bilimlerde araştırma yöntemleri - SSPS uygulamal, Adapazarı: Sakarya Kitabevi.

Brodersen, M., \& Manolova, P. (2008). Packaging designs a brand-building tool, (Unpublished master's thesis). International Marketing and Brand Management, School of Economics and Management, Lund University, Sweden.

Carpenter, C. E., Cornforth, D. P., \& Whittier, D. (2001). Consumer preferences for beef color and packaging did not affect eating satisfaction, Meat Science, 57, 359-363. http://dx.doi.org/10.1016/S0309-1740(00) 00111-X

Dantas, M. I. S., Minim, V. P. R., Deliza, R., \& Puschmann, R. (2004). The effect of packaging on the perception of minimally processed products, Journal of International Food \& Agribusiness Marketing, 16(2), 71-83. http://dx.doi.org/10.1300/J047v16n02_05.

Dilber, F., Dilber A., \& Karakaya, M. (2012). Gıdalarda ambalajın önemi ve tüketicilerin satın alma davranışlarına etkisi (Karaman ili örneği), e-Gifder, Gümüşhane Üniversitesi Illetişim Fakültesi Elektronik Dergisi, 3, 159-190.

Erciş, A., Yapraklı, Ş., \& Can, P. (2009). Güçlü ve güçsüz markalarda marka bilgisi, marka ilişkileri ve satın alma davranışları arasındaki farklılıkların incelenmesi, Marmara Üniversitesi İktisadi ve İdari Bilimler Fakültesi Dergisi, 26(1), 157-190.

Erdil, T. S., \& Uzun, Y. (2009). Marka olmak, İstanbul: Beta Basım Yayım Dă̆ııım A. Ş.

Gökalp, F. (2007). Gıda ürünleri satın alma davranışında ambalajın rolü, Ege Akademik Bakış, 7(1), 79-97.

Kırdar, Y. (2003). Marka stratejilerinin oluşturulması: Coca-Cola örneği, Review of Social, Economic \& Business Studies, 3(4), 233-250.

Kocabaş, F., Elden, M., \& Çelebi, S. İ. (1999). Marketing PR, MediaCat Yayınları.

Kocamanlar, E. (2009). Ambalaj ve fonksiyonları, Ambalaj Bülteni, 34-38.

Koyuncu, K. (2007). Marka ve ambalajın tüketici satın alma davranışları üzerine etkisi, (Yayınlanmamış Yüksek Lisans Tezi), Niğde Üniversitesi Sosyal Bilimler Enstitüsü, Niğde, Türkiye.

Meral, P. S. (2011). Kurumsal kimlik ve marka, Ankara: Detay Yayınc1lı.

Nakip, M. (2004). Pazarlama araştırmalarına giriş (SPSS destekli), Ankara: Seçkin Yayınevi.

Örücü, E., \& Tavşancı, S. (2001). Gıda ürünlerinde tüketicinin satın alma eğilimini etkileyen faktörler ve ambalajlama, Muğla Üniversitesi Sosyal Bilimler Enstitüsü Dergisi, 3, Retrieved from http://sobbiad.mu.edu.tr/index.php/asd/article/viewFile/59/64.

Rex, J., Wai, S., \& Lobo, A. (2004). An exploratory study into the impact of colour and packaging as stimuli in the decision making process for a low involvement non-durable product, In: ANZMAC 2004 Proceedings, Wellington.

Sezgin, M., Haşıloğlu, S. B., \& Zerenler, M. (2008). Pazarlamada ambalajlama ve un mamulü ambalajının müşteri üzerindeki imajını belirlemeye yönelik bulanık mantık yaklaşımı, Marmara Üniversitesi İktisadi ve İdari Bilimler Fakültesi Dergisi, 25(2), 721-742.

Sütütemiz, N., Çiftyıldız, S. S., \& Konuk, F. A. (2009). Paketlenmiş süt için ambalaj özelliklerinin algılanan önemi ve satın alma davranışına etkisi: İstanbul ili örneği, Akademik Gıda, 7(6), 18-28. 
Tek, Ö. B. (1997). Pazarlama ilkeleri: Global yönetimsel yaklaşım Türkiye uygulamaları, İzmir: Beta Yayınları.

Teke, B. (2014). Gıda ürünleri ambalajının tüketicilerin satın alma davranışları üzerine etkisi (Ankara ili Mamak ilçesi örneği), (Yayınlanmamış Yüksek Lisans Tezi), Gaziosmanpaşa Üniversitesi Fen Bilimleri Enstitüsü, Tokat, Türkiye.

Tosun, N. B. (2014). Marka yönetimi, Beta Yayınları

Underwood, R. L. (2003). The communicative power of product packaging: Creating brand identity via lived and mediated experience, Journal of Marketing Theory and Practice, 11(1), 62-76. http://dx.doi.org/10.1080/10696679.2003.11501933

Uztuğ, F. (2008). Markan kadar konuş: marka iletişimi stratejileri, İstanbul: MediaCat Yayınları.

Whaling, A. M. (2007). The effect of packaging attributes on consumer perception of cherry juice (Unpublished master's thesis), Michigan State University, Department of Packaging, USA.

Yıldız, Ö. E. (2010). Ambalajın marka farkındalığı yaratmadaki etkisi, Gazi Üniversitesi İletişim Kuram ve Araştırma Dergisi, 31, 181-194.

Yükselen, C. (2003). Pazarlama: Illkeler-yönetim, Ankara: Detay Yayıncılık.

\section{Copyrights}

Copyright for this article is retained by the author(s), with first publication rights granted to the journal.

This is an open-access article distributed under the terms and conditions of the Creative Commons Attribution license (http://creativecommons.org/licenses/by/3.0/). 